\title{
Simulated Acid Rain and its Possible Impacts on Grout
}

\author{
Eduardo Antonio Maia Lins \\ Dept. of Environmental Engineering, Catholic University of \\ Pernambuco, Recife, Brazil.
}

Anna Kattaryne Cavalcante dos Santos

Chemical Engineering, Catholic University of Pernambuco, Recife, Brazil.

\begin{abstract}
The urban environment, due to its characteristics of population concentration, causes changes in the original environment. These changes, when studying the degradation of buildings, especially of concrete structures, include the occurrence of acid rain, deposition of solid particles and the release of carbon dioxide into the atmosphere, responsible for the carbonation of concrete and consequent corrosion of the reinforcement. Given these facts, the Boa Vista neighborhood, located in the Metropolitan Region of Recife, Brazil, can be considered an urban environment conducive to the generation of acid rain due to its high flow of vehicles, in addition to having large buildings, around 1500 housing units. . This study aimed to analyze the quality of rainwater in the neighborhood and to compare the content of existing compounds in runoff waters, with the rate of ions dragged from grout specimens, exposed to laboratory simulation of a rain intense in a natural way. Based on physical chemical analyzes carried out, the average $\mathrm{pH}$ found for the rains collected from the atmosphere was 6.10 , indicating a slight acidity. The ions found in the highest concentration were $\mathrm{Cl}^{-}$and $\mathrm{Ca}^{+2}$. In addition to the content of ions incorporated by the building's water flow, it was about six times smaller than the residual material integrated in the water that came into contact with the simulated specimens, when comparing the data obtained for the $\mathrm{pH}$ range found in water drained from the building in a natural way $(\mathrm{pH}=5.5-6.0)$.
\end{abstract}

Keywords:- Precipitation; Acidity; Specimens; Building.

\section{INTRODUCTION}

The chemical composition of the precipitations is influenced by factors such as burning of fuels, decomposition of organic matter, direction of the winds, proximity to the sea, amount and frequency of rain in the study site. Since its quality is related to the atmosphere of its formation (NETO, 2003; JAQUES, 2005; TORDO, 2004; SANTOS et al., 2018).

Due to the efficiency of "atmospheric cleaning" by rainwater, the characterization of the acidity of this wet deposition, the effect of the association of pollutants in it, is important to measure the environmental and material damage in the environment. However, as mentioned by

\author{
Sérgio Carvalho de Paiva \\ Dept. of Chemical Engineering, Catholic University of \\ Pernambuco, Recife, Brazil. \\ Luiz Vital Fernandes Cruz da Cunha \\ Dept. of Biological Sciences, Catholic University of \\ Pernambuco, Recife, Brazil.
}

Fornaro et al. (2003) only pH measurements are not enough to assess the degree of "contamination" of these precipitation waters, which is why more detailed research generally covers the analysis of chloride $\left(\mathrm{Cl}^{-}\right)$, ammonium $\left(\mathrm{NH}_{4}{ }^{+}\right)$, sodium ions $\left(\mathrm{Na}^{+}\right)$, potassium $\left(\mathrm{K}^{+}\right)$, calcium $\left(\mathrm{Ca}^{+2}\right)$ and magnesium $\left(\mathrm{Mg}^{+2}\right)$, heavy metals cadmium $\left(\mathrm{Cd}^{+}\right)$, lead $\left(\mathrm{Pb}^{+2}\right)$, copper $\left(\mathrm{Cu}^{+}\right)$and organic species such as carboxylic acids.

Given these facts, the Boa Vista neighborhood, located in the metropolitan region of Recife, can be considered an area that has a tendency to acid deposition, as it has a high flow of vehicles, about 310 thousand people circulate on the road per day, $10 \%$ in private transport, more than $50 \%$ on buses and less than $1 \%$ are bicycle users; in addition to having large buildings, around 1500 housing units and about 370 commercial establishments, where the oldest ones use marble in their façades and limestone sculptures (CONDEPE, 2013; CTTU, 2018).

This study, therefore, aimed to analyze the quality of rainwater in the neighborhood and to compare the content of existing compounds in runoff waters, with the rate of ions dragged from grout specimens, exposed to laboratory simulation. of an intense rain in a natural way. The objective is to verify possible changes in the region's ecosystems and in civil construction, since the acid $\mathrm{pH}$ rain causes an attack on the cement which is alkaline, leading to the solubilization of its components and aggregates, since the humidity inside the pores interferes in the corrosion rate, this being an electrochemical process, requiring water so that the ions can move and generate corrosion current (AMORIM, 2010). Consequently, acidity and compounds diluted by rainwater in contact with porous materials generate depassivation and a consequent decrease in its resistance.

Based on physical chemical analyzes carried out according to the American Public Health Association (APHA, AWWA, WEF, 2012), the average $\mathrm{pH}$ found for the rains collected from the atmosphere was 6.10 , indicating a slight acidity. The ions found in the highest concentration were $\mathrm{Cl}^{-}$and $\mathrm{Ca}^{+2}$, results that could be compared with research developed in other regions of Brazil (TRESMONDI et al., 2005; SOUZA et al., 2006; PEREIRA, 2014), which served as a parameter for the present sampling work in Recife. 


\section{MATERIALS AND METHODS}

The collections carried out in accordance with NBR 13,969 of the Brazilian Association of Technical Standards (1997) modified for rainwater, were carried out at the Catholic University of Pernambuco (UNICAP), located in Boa Vista ( $\left.8^{\circ} 03^{\prime} 25^{\prime \prime S}, 34^{\circ} 52^{\prime} 52^{\prime \prime} \mathrm{O}\right)$, a neighborhood in the metropolitan region of Recife and chosen as a collection point because it is a plural space. Based on characteristics such as number of inhabitants; large buildings of various architectural styles (limestone-based sculptures) and different construction periods; in addition to high flow of vehicles. Factors responsible for the incidence of the acid rain phenomenon.

Fifty-four samples were collected for analysis of rainwater and fifty for the study of water drained from an asbestos cement tile, from August 2018 to July 2019.

The samples collected from the atmospheric and runoff rain were stored in properly sterilized plastic containers, identified numerically and the collection was carried out at strategic points of UNICAP, on totally open surfaces, so that there was no interference from vegetation and particles such as leaves, branches and small stones. The collection was carried out only at the beginning of the precipitation, not being exposed to dry deposition.

After collection, the water samples were taken to the UNICAP laboratory and the physical chemical analyzes were performed according to the American Public Health Association (APHA, AWWA, WEF, 2012), standard methodology for examining water and wastewater. The parameters adopted, as they are more accessible, for atmospheric water were $\mathrm{pH}$, total hardness, calcium, magnesium, chlorides, sulfates, sodium, potassium and acidity. And for runoff water were total hardness, calcium and magnesium.

In order to verify the impacts generated by the incidence of acid rain on civil construction materials and to carry out a subsequent comparison with the building runoff water, simulators of intense rain were prepared in the UNICAP laboratory in grout specimens, with the following composition : trait used 1: 3: 0.48 (cement; sand; water); cement used CP II-Z-32 RS Nacional. Figure 1 shows the elaboration of the specimens with $1,963.50 \mathrm{~mm}^{2}$ of surface.

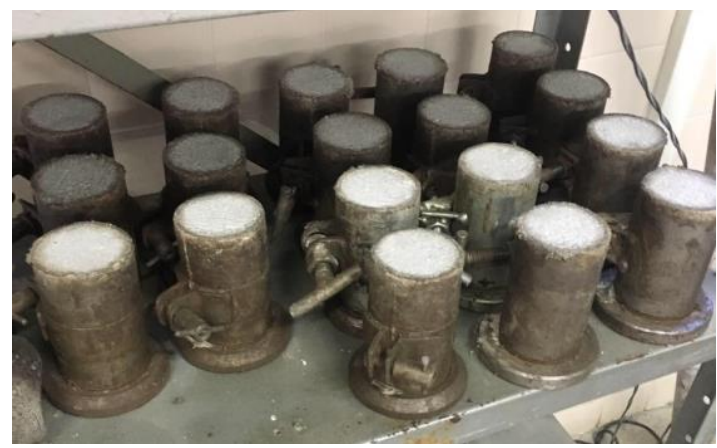

Fig 1:- Preparation of the specimens. Source: The Authors, 2020.

\section{A. First Method}

Four four-liter beakers were placed, each containing an acid solution of different $\mathrm{pH}$ (4.0, 4.5, 5.0 and 5.5). Three specimens were placed in each beaker, immersed in solution. The pH's were monitored so that they did not fluctuate sharply. Aliquots were collected daily in order for the ions dragged from the specimens to be verified by means of physical chemical analyzes. The specimens were immersed for 57 days, from august to October 2018. They were also placed in contact with distilled water to simulate a neutral rain, as a parameter. Figure 2 shows the rain simulation scheme on cement structures.

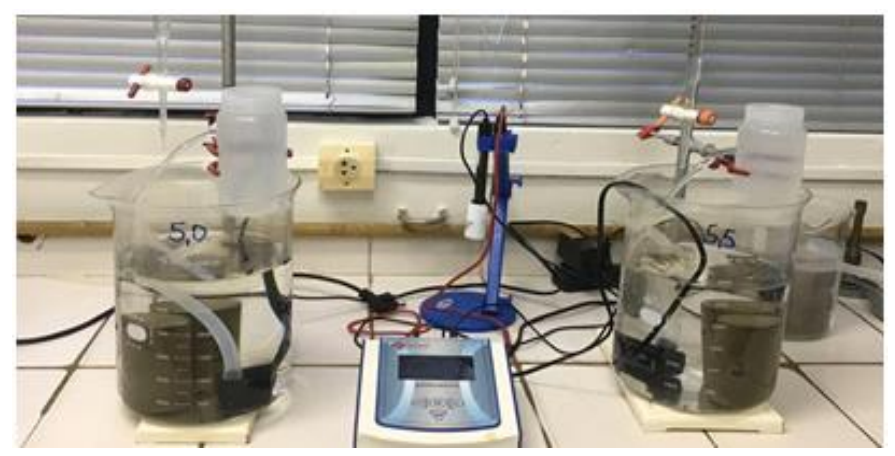

Fig 2:- Scheme used with specimens immersed in solution (1st method).

Source: The Authors, 2020.

\section{B. Second Method}

To simulate intense rain in a more natural way, a scheme using a showerhead was set up. In the same way as in the 1 st method, the specimens were exposed to rain with different $\mathrm{pH}$ 's, but in such a way that they were not immersed in solution but receiving constant rain. The 2 nd method was divided into two stages, the first was applied from $10 / 22 / 2018$ to $12 / 4 / 2018$, about 43 days. Then, in the interval from $05 / 12 / 2018$ to $21 / 12 / 2018$, that is, 16 days of intense rain. Figure 3 shows the new arrangement made.

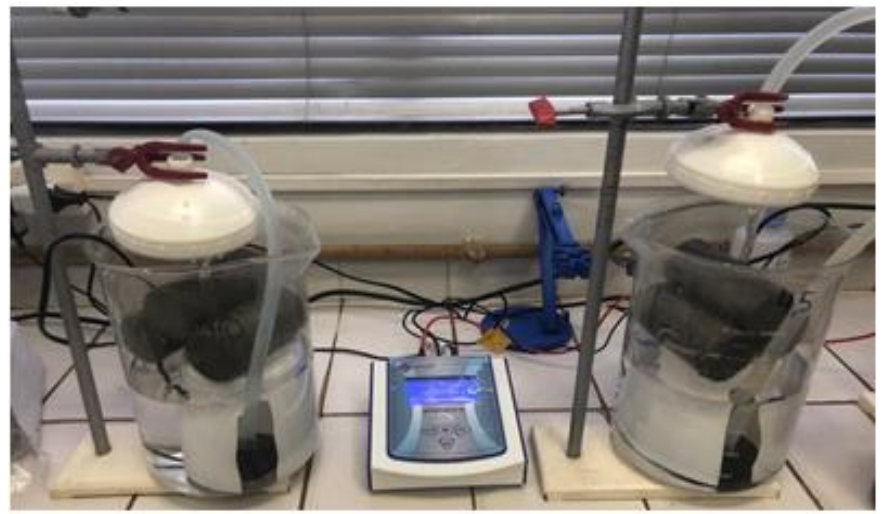

Fig 3:- Scheme used with specimens exposed to intense rain through showers (2nd method).

Source: The Authors, 2020.

It is important to note that aquarium pumps were used to keep the water circulating and minimize the effects of particle deposition on the bottom of the beaker. 


\section{RESULTS AND DISCUSSION}

Samples of precipitation were collected on different days and times, between the second semester of 2018 and the first semester of 2019, where they were tagged and cataloged as Unicap 81 to Unicap 133, characterized from the place and date of capture. The entire physical-chemical test was based on Standard Methods (APHA, AWWA, WEF, 2012), being a methodology highly guaranteed by IUPAC (International Union of Pure and Applied Chemistry).

Nine parameters were carried out, each test performed in triplicate, totaling 1,458 determinations. The representations of the results obtained from the rain analyzes in this period are described in Table 1, in the form of minimum, maximum and average. To verify changes in the natural concentrations of rainwater due to air pollutants.

The characterization of rainwater is based on the balance between pure water and atmospheric carbon dioxide $\left(\mathrm{CO}_{2}\right)$, being perceptible by the values obtained for acidity in Table 1 in the samples. As well as, it is observed that the $\mathrm{pH}$ resulting from the collections presented, on average, the value of 6.10 , that is, below 7.0, characterizes the atmospheric precipitation in the neighborhood of Boa Vista as slightly acidic in the space of time.

\begin{tabular}{|c|c|c|c|c|c|c|c|c|c|}
\hline & pH & $\begin{array}{c}\text { Total } \\
\text { Hardness }\end{array}$ & Calcium & Magnesium & Chloride & Sulfate & Sodium & Potassium & Acidity \\
\hline & - & $\begin{array}{c}\mathrm{mg} / \mathrm{L} \\
\mathrm{CaCO}_{3}\end{array}$ & $\mathrm{mg} / \mathrm{L} \mathrm{Ca}^{++}$ & $\mathrm{mg} / \mathrm{L} \mathrm{Mg}^{++}$ & $\mathrm{mg} / \mathrm{L} \quad \mathrm{Cl}^{-}$ & $\begin{array}{l}\mathrm{mg} / \mathrm{L} \\
\mathrm{SO}_{4}^{-2}\end{array}$ & $\mathrm{mg} / \mathrm{L} \mathrm{Na}^{+}$ & $\mathrm{mg} / \mathrm{L} \quad \mathrm{K}^{+}$ & $\frac{\mathrm{mg} / \mathrm{L}}{\mathrm{CO}_{2}}$ \\
\hline Maximum & 9,83 & 280,00 & 24,05 & 58,32 & 90,00 & 6,35 & 52,27 & 20,00 & 22,00 \\
\hline Average & 6,10 & 46,47 & 7,56 & 6,80 & 21,51 & 1,16 & 5,19 & 1,91 & 10,06 \\
\hline Minimum & 3,56 & 5,00 & 0,00 & 0,00 & 3,00 & 0,00 & 0,00 & 0,00 & 4,40 \\
\hline
\end{tabular}

Table 1:- Results found for rain samples collected from the atmosphere.

Source: The Authors (2020).

In research carried out by Pereira (2014) in Lajeado / $\mathrm{RS}$, the $\mathrm{pH}$ of the local rains averaged 6.64. On the other hand, the average value for the parameter in the João Aranha neighborhood, in Paulínia / SP, was 4.83 (TRESMONDI et al., 2005). Thus, the Recife district is within the group of locations with possible impacts on biota and influence on corrosion by acid rain.

The average concentrations of $\mathrm{Cl}^{-}$and $\mathrm{Na}^{+}$(21.51 and $5.19 \mathrm{mg} / \mathrm{L}$, respectively) were lower than those found in Ilha Grande / RJ (SOUZA et al., 2006), because despite the Boa Vista neighborhood being located in a coastal city, and such ions are present from the maritime influence, the speed of the winds that travel through the research region are not sufficient for the high drag of these particles.

The samples showed significant but not high mean concentrations of $\mathrm{Ca}^{+2}, \mathrm{Mg}^{+2}$ and $\mathrm{K}^{+}$ions (7.56; 6.80 and $1.91 \mathrm{mg} / \mathrm{L}$, respectively) due to the presence of large buildings, paved streets and circulation of people in the environment, in addition to the low index for the ion $\mathrm{SO}_{4}{ }^{-2}$, despite the high flow of cars. This fact can be justified by the dilution in the atmosphere, since the volume of rain in the period was relevant (Figure 4), implying the lower concentration of a certain element.

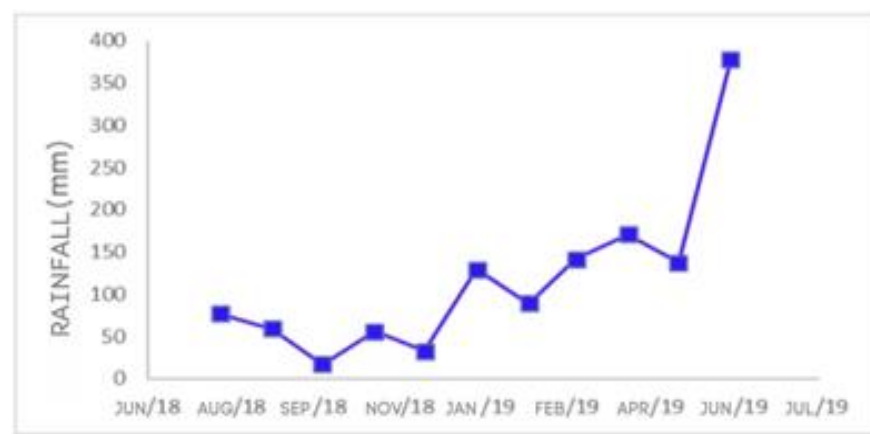

Fig 4:- Monitoring of rainfall in the Boa Vista / PE neighborhood.

Source: Prepared by the author based on APAC -

Pernambucana Agency of Waters and Climate, 2019.

In order to verify also how the quality of the rain water changes along the way to the storage system, and the qualification of the ions dragged from the civil construction, since the water transports substances with an exchange with the environment; and rain and relative humidity are factors that have a direct correlation with material degradation reactions (AMORIM, 2010; RINCÓN, 1998), the data obtained from the rainwater drained by the tile and the schemes with specimens are arranged in Tables 2, 3, 4 and 5 . 
ISSN No:-2456-2165

\begin{tabular}{|c|c|c|c|}
\hline & Total Hardness & Calcium & Magnesium \\
\hline & $\mathrm{mg} / \mathrm{L} \mathrm{CaCO}_{3}$ & $\mathrm{mg} / \mathrm{L} \mathrm{Ca}^{++}$ & $\mathrm{mg} / \mathrm{L} \mathrm{Mg}^{++}$ \\
\hline Maximum & 210,00 & 36,07 & 43,74 \\
\hline Average & 44,11 & 10,00 & 4,47 \\
\hline Minimum & 10,00 & 2,00 & 0,00 \\
\hline
\end{tabular}

Table 2:- Results of analyzes on rain samples collected by runoff (tile).

Source: The Authors (2020).

The acids on the concrete work by destroying its porous system and producing a complete transformation in the hardened cement paste. The result of these actions is the loss of mass and reduction of the concrete section. These losses occur in successive layers, starting from the exposed surface, the rate of degradation being proportional to the amount and concentration of the acid in contact with the material. It appears that the attack occurs at $\mathrm{pH}$ values close to or below 6.5 (LAPA, 2008).

\begin{tabular}{|c|c|c|c|c|c|}
\hline Identification & Time & pH & Total Hardness & Calcium & Magnesium \\
\hline Specimen & Hour & - & $\left(\mathrm{mg} / \mathrm{L} \mathrm{CaCO}_{3}\right)$ & $\left(\mathrm{mg} / \mathrm{L} \mathrm{Ca}{ }^{++}\right)$ & $\left(\mathrm{mg} / \mathrm{L} \mathrm{Mg}^{++}\right)$ \\
\hline \multicolumn{6}{|c|}{ 1st Method } \\
\hline 1 & 1296 & 4,0 & 1820,00 & 533,06 & 119,07 \\
\hline 2 & 1296 & 4,5 & 935,00 & 312,62 & 37,67 \\
\hline 3 & 1296 & 5,0 & 700,00 & 242,48 & 23,09 \\
\hline 4 & 1296 & 5,5 & 505,00 & 186,37 & 9,72 \\
\hline 5 & 1200 & Testimonial & 80,00 & 12,02 & 12,15 \\
\hline
\end{tabular}

Table 3:- Results of the analysis in the waters collected from the simulation with immersed bodies.

Source: The Authors (2020).

\begin{tabular}{|c|c|c|c|c|c|c|}
\hline Identification & Time & pH & Total Hardness & Calcium & Magnesium \\
\hline Specimen & Hour & - & $(\mathrm{mg} / \mathrm{L} \mathrm{CaCO})$ & $\left(\mathrm{mg} / \mathrm{L} \mathrm{Ca}^{++}\right)$ & $\left.(\mathrm{mg} / \mathrm{L} \mathrm{Mg})^{++}\right)$ \\
\hline \multicolumn{7}{|c|}{ 2nd Method - 1 Stage } \\
\hline 1 & 1032 & 4,0 & 665,00 & 122,24 & 87,48 \\
\hline 2 & 1032 & 4,5 & 565,00 & 120,24 & 64,40 \\
\hline 4 & 1032 & 5,0 & 470,00 & 108,22 & 48,60 \\
\hline 5 & 1032 & 5,5 & 390,00 & 86,17 & 42,53 \\
\hline
\end{tabular}

Table 4:- Results of the analysis in the waters collected from the simulation with specimens under intense rain for 43 days.

Source: The Authors (2020).

\begin{tabular}{|c|c|c|c|c|c|c|}
\hline Identification & Time & pH & Total Hardness & Calcium & Magnesium \\
\hline Specimen & Hour & - & $(\mathrm{mg} / \mathrm{L} \mathrm{CaCO} 3)$ & $\left(\mathrm{mg} / \mathrm{L} \mathrm{Ca}^{++}\right)$ & $\left.(\mathrm{mg} / \mathrm{L} \mathrm{Mg})^{++}\right)$ \\
\hline \multicolumn{7}{|c|}{ 2nd Method - 2 Stage } \\
\hline 1 & 386 & 4,0 & 600,00 & 196,39 & 26,73 \\
\hline 2 & 386 & 4,5 & 485,00 & 172,34 & 13,37 \\
\hline 3 & 386 & 5,0 & 425,00 & 158,32 & 7,29 \\
\hline 4 & 386 & 5,5 & 285,00 & 106,21 & 4,86 \\
\hline 5 & 1200 & Testimonial & 80,00 & 12,02 & 12,15 \\
\hline
\end{tabular}

Table 5:- Results of the analysis in the waters collected from the simulation with specimens under intense rain for 16 days.

Source: The Authors (2020).

When acid rain comes in contact with the cement paste, they tend to hydrolyze or dissolve products containing calcium, since calcium hydroxide $\left(\mathrm{Ca}(\mathrm{OH})_{2}\right)$ is the constituent that, due to its high water solubility, it is more sensitive to electrolysis, causing the chemical component to leach (LAPA, 2008). The product of this process, in addition to causing the loss of strength of the concrete, can interact with $\mathrm{CO}_{2}$, present in the atmosphere, resulting in the precipitation of white crusts of calcium carbonate $\left(\mathrm{CaCO}_{3}\right)$ on the surface, as can be seen in equations 1,2 and 3 (ISAIA, 2005), an effect called concrete carbonation.

$\mathrm{Ca}(\mathrm{OH})_{2} \rightarrow \mathrm{Ca}^{+2}+2 \mathrm{OH}^{-}$(in the aqueous phase of the pores) (Equation 1)

$\begin{aligned} & \mathrm{CO}_{2}+2 \mathrm{HO} \rightarrow \\ & \text { (Equation 2) }\end{aligned} \quad \mathrm{CO}_{3}^{-2}+\mathrm{H}_{2} \mathrm{O}\left(\mathrm{CO}_{2}\right.$ solubilization)

$\mathrm{Ca}^{+2}+\mathrm{CO}_{3}^{-2} \rightarrow \mathrm{CaCO}_{3}$ (carbonation) (Equation 3) 
In the waters percolated by the porous materials, several entrained ions are dissolved, however, it is perceived due to the total hardness, that the largest residual charge in the runoff waters of both rain and simulations is composed of the $\mathrm{Ca}^{+2}$ ion, about $30 \%$, confirming the effect of acceleration on the corrosion of materials with limestone as a result of contact with water with a $\mathrm{pH}$ below 7.0. Given the fact that the concrete has a $\mathrm{pH}$ of the order of 12.5 , mainly due to $\mathrm{Ca}(\mathrm{OH})_{2}$, and its transformation into $\mathrm{CaCO}_{3}$ causes the $\mathrm{pH}$ of the equilibrium solution to decrease, from 12.5 to 9.4 , important factor for the beginning of corrosion (LAPA, 2008). Reaffirming the fact that although many different types of stone are used in sculptures or buildings, the most vulnerable to attacks by acid rain are marble and limestone (AHERNE et al., 2016).

The levels of both cations $\left(\mathrm{Ca}^{+2}\right.$ and $\left.\mathrm{Mg}^{+2}\right)$ were even higher than those of rainwater collected from the atmosphere, the flow levels were only slightly higher, but the simulation rain contains an average of 6 times more ions in the $\mathrm{pH}$ range $=5.5-6.0$. And making the comparison between the dragging of components between the runoff of the tile and that of the simulations, it is understood that the content of the runoff ions is much lower than that of the simulated rain, since the acid incidence in the specimen in laboratory was much more intense. And when it comes to complete immersion of the porous material, the effects are even more harmful.

In numerical terms, from the fully immersed specimens, when comparing the results of the analysis of total hardness, calcium and magnesium between the highest and lowest $\mathrm{pH}$ simulated, a large discrepancy is noticed. At a lower $\mathrm{pH}$ (equal to 4.0) there was a higher drag of $\mathrm{CaCO}_{3}$, more than $1300 \mathrm{mg} / \mathrm{L}$, while for $\mathrm{Ca}^{+2}$ and $\mathrm{Mg}^{+2}$, about 347 $\mathrm{mg} / \mathrm{L}$ and $109 \mathrm{mg} / \mathrm{L}$ more were dragged. than at $\mathrm{pH}=5.5$, respectively. When considering the levels of ions leached by the 2nd method, it is observed that the levels are much lower than the method of total immersion, even so, at a lower $\mathrm{pH}$ the results are, on average, twice the rate at a higher $\mathrm{pH}$.

It appears that lower $\mathrm{pH}$ waters $(\mathrm{pH}=4.0)$ are the most aggressive, showing that the closer to neutrality the lower the drag of ions from the structures. Therefore, in a historic city like Recife, the possible damage to sculptures, monuments and buildings by wet deposition stands out. Since acid precipitation is only an aggressive agent, added to different destructive factors, which can occur in isolation or together, result in degradation.

As for the exposure time, the longer the incidence of low $\mathrm{pH}$ rainwater under the material, the higher the concentration of ions incorporated into the fluid, as verified by step 1 of the 2 nd method. And with the removal of this type of rain from the cement components, its resistance can be reduced by around $40 \%$, as evidenced by another author, in work on the same research project.

\section{CONCLUSIONS}

From the analyzes carried out, it can be concluded that there is a deterioration in air quality and, consequently, in rainwater in the Boa Vista neighborhood. Effect evidenced by the quantification of contaminating ions and the incidence of lightly acid rain in the region within the study period, a consequence of the unbridled growth of this urban atmosphere. However, it is necessary to continue the research to reaffirm the gradual decrease in the $\mathrm{pH}$ of the rains over time.

In addition to the impacts on biota, the corrosive effect of acid wet deposition on buildings and works of art is clear. The surfaces of these structures subject to chemical attacks must be protected with paints, resins, and other waterproofing barriers. The level of protection is quite variable, but it is essential that the antacid barrier is adherent and also resistant to mechanical actions.

The lower $\mathrm{pH}$ waters are the most aggressive to limestone materials. The longer the exposure period and the greater the contact surface with the fluid, the greater the negative impacts. In simulations that incorporated percolated water, there was a difference of more than $100 \%$ in the content of ions found in relation to natural runoff waters, showing acid precipitation as a destructive agent.

\section{REFERENCES}

[1]. AGÊNCIA ESTADUAL DE PLANEJAMENTO E
PESQUISAS DE PERNAMBUCO CONDEPE/FIDEM. Municípios da Região Metropolitana do Recife. Disponível em:<http://www.bde.pe.gov.br/visualizacao/Visualiza cao_formato2.aspx ?codFormatacao $=695 \&$ CodInform acao=798\&Cod=1>. Acesso em: 23 jan. 2019.

[2]. AGÊNCIA PERNAMBUCANA DE ÁGUAS E CLIMA - APAC. Monitoramento mensal das chuvas no bairro da Boa Vista [mensagem pessoal]. Mensagem recebida por <mmfcarvalho@live.com> em 19 jun. 2019.

[3]. AHERNE, J.; GAY, D. A.; LEHMANN, M. B. Acid rain and its environmental effects: Recent scientific advances. Atmospheric Environment, [S. 1.], v. 146, 2016.

[4]. AMORIM, Anderson Anacleto. Durabilidade das estruturas de concreto armado aparentes. 2010. $73 \mathrm{f}$. Monografia (Especialização em Construção Civil) Curso de Especialização em Construção Civil, Universidade Federal de Minas Gerais, Belo Horizonte, 2010.

[5]. APHA, AWWA, WEF. Standard Methods for the Examination of Water and Wastewater. $22^{\mathrm{a}}$ ed. Washington: Associação Americana de Saúde Pública, APHA. 2012.

[6]. ASSOCIAÇÃO BRASILEIRA DE NORMAS TÉCNICAS. ABNT NBR 13.969: Tanques sépticos unidades de tratamento complementar e disposição final dos efluentes líquidos - Projeto, construção e operação. Rio de Janeiro, 1997. 
[7]. AUTARQUIA DE TRÂNSITO E TRANSPORTE URBANO DO RECIFE - CTTU. Prefeitura do Recife apresenta projeto da Nova Conde da Boa Vista, 2018. Disponível em: <http://cttu.recife.pe.gov.br/prefeiturado-recife-apresenta-projeto-da-nova-conde-da-boavista>. Acesso em: 01 fev. 2019.

[8]. FORNARO, A.; GUTZ, I. G. R. Wet Deposition and Related Atmospheric Chemistry in the São Paulo Metropolis, Brazil: Part 2 - Contribution of Formic and Acetic Acids. Atmospheric Environment, [S. 1.], v. 37, 2003.

[9]. ISAIA, Geraldo Cechella. Concreto: Ensino, Pesquisas e Realizações. São Paulo: IBRACON, 2005. v. 2.1989.

[10]. JAQUES, Reginaldo Campolino et al. Qualidade da água de chuva no município de Florianópolis e sua potencialidade para aproveitamento em edificações. 2005. 101 f. Dissertação (Mestrado em Engenharia Ambiental) - Programa de Pós-Graduação em Engenharia Ambiental, Universidade Federal de Santa Catarina, Florianópolis, 2005.

[11]. LAPA, José Silva. Patologia, recuperação e reparo das estruturas de concreto. 2008. 55 f. Monografia (Especialização em Construção Civil) - Curso de Especialização em Construção Civil, Universidade Federal de Minas Gerais, Belo Horizonte, 2008.

[12]. NETO, C. O. A. Segurança Sanitária das Águas de Cisternas Rurais. $4^{\circ}$ Simpósio Brasileiro de Captação de Água de Chuva. Disponível em <http://www.abcmac.org.br/files/simposio/4simp_cice ro_segurancasanitariasdaaguadecisterna.pdf $>$. Acesso em: 15 jan. 2019.

[13]. PEREIRA, Alini Patricia. Avaliação da qualidade da água da chuva. 2014. 27 f. Trabalho (Técnico em Química) - Curso Técnico em Química, Centro Universitário Univates, Lajeado, 2014.

[14]. RINCÓN, Oladis Trocónis et al. Manual de inspeccion, evaluación y diagnostico de corrosion en estructuras de hormigón armado - Programa Iberoamericano de Ciência y Tecnologia para el desarrollo. 2. ed. [S. 1.]: DURAR: Red Temática XV. B Durabilidad de la Armadura, 1998.

[15]. SANTOS, Anna Kattaryne Cavalcante et al. Diagnóstico da potabilidade das águas pluviais na cidade do Recife: estudo de caso no bairro da Boa Vista. Recife: ENHTEC, 2018.

[16]. SOUZA, P. A.; MELLO, W. Z.; MALDONADO, J.; EVANGELISTA, H. Composição Química da Chuva e Aporte Atmos $\neg$ férico na Ilha Grande, RJ. Química Nova, [S. 1.], v. 29, 2006.

[17]. TORDO, Olga Catarina. Caracterização e avaliação do uso de águas de chuva para fins potáveis. 2004. Dissertação (Mestrado em Engenharia Ambiental) Programa de Pós-Graduação em Engenharia Ambiental, Universidade Regional de Blumenau, Blumenau. 2004.

[18]. TRESMONDI, Ana Claudia et al. Avaliação de pH e composição iônica das águas de chuva em PaulíniaSP. Engenharia Ambiental: Pesquisa e Tecnologia, [S. 1.], v. 2, n. 1, 2005. 